\title{
ANALISIS KUALITATIF DAN KUANTITATIF KANDUNGAN EUGENOL DALAM JAMU EMPON-EMPON
}

\author{
Dewi Iva Rinia ${ }^{* 1}$, Indira Pipit Miranti², Anisa Annastasya ${ }^{3}$ \\ 1,3 S1 Farmasi STIKes Ibnu Sina Ajibarang, Indonesia \\ ${ }^{2}$ D3 Analis Farmasi dan Makanan, Stikes Ibnu Sina Ajibarang, Indonesia \\ e-mail: ${ }^{* 1}$ ivarina008@gmail.com, 2 indira.pipit@gmail.com, 3 anastasyatasya38@gmail.com,
}

\begin{abstract}
ABSTRAK
Keanekaragaman tanaman obat yang dimiliki Indonesia sangat banyak, serta penggunaannya dalam masyarakt juga beragama. Salah satu jamu yang sering digunakan sebagai obat yaitu eugenol. Dimana eugenol memiliki fungsi sebagai analgetik, animikroba, dan immunomodulator. Sehingga sangat penting untuk mengetahui kandungan eugenool dalam jamu empon-empon. Penelitian kualitatif dan kuantitaif dilakukan dengan metode KLT-densitometri dengan pelarut toluen: etil asetat: metanol rasio (65: 2,5: 32)v/v. Kurva baku dibuat dengan konsentrasi 10; 15; 20; 25; dan $30 \mu \mathrm{L} / \mathrm{ml}$. dipeoleh hasil kandungan eugenol dalam sampel tersebut sebanyak 49,28 $\mu \mathrm{l} / \mathrm{ml}$.
\end{abstract}

Kata kunci: Empon-empon, Eugenol, Klt-densitometri.

\section{ABSTRACT}

The diversity of medicinal plants owned by Indonesia is very large, and its use in the community is also religious. One of the herbs that are often used as medicine is eugenol. Where eugenol has a function as an analgesic, antimicrobial, and immunomodulator. So it is very important to know the eugenool content in empon-empon herbs. Qualitative and quantitative research was conducted by TLC-densitometry method with toluene:ethyl acetate:methanol ratio $(65: 2.5: 32) \mathrm{v} / \mathrm{v}$ as solvent. Standard curves were made with a concentration of $10 ; 15 ; 20 ; 25$; and $30 \mathrm{~L} / \mathrm{mL}$. the results obtained that the eugenol content in the sample was $49.28 \mathrm{l} / \mathrm{mL}$.

Keywords: empon-empon, eugenol, TLC-densitometry

\section{PENDAHULUAN}

Di Indonesia, masyarakat cenderung menggunakan ramuan-ramuan atau kombinasi tanaman yang berbentuk jamu. Jamu tersebut didapatkan secara turun-temurun berdasarkan pegalaman nenek moyang. Jamu yang dipercaya memiliki aktivitas sebagai peningkat daya tahan tubuh/ atau sistem imun manusia yaitu jamu empon-empon yang terdiri dari tanaman jahe, temulawak, kunyit, kayu manis dan sereh [1]. Berdasarkan beberapa penelitian yang sudah pernah dilakukan terhadap tanaman-tanaman tersebut secara tunggal seperti jahe (Zingiberofficinale var.rubrum) memiliki kandungan aktif berpengaruh terhadap aktivitas reproduksi adalah arginin. Arginin merupakan asam amino non-esensial yang berperan aktif dalam sistem ketahanan tubuh dan imunitas seluler [2], selanjutnya rimpang kunyit (Curcumalonga L.) dan temulawak (Curcuma xantorhiza Roxb.) telah terbukti memiliki aktivitas immunomodulator, antiinflamasi, dan antivirus [3], lalu kulit kayu manis (Cinnamomumburmannii) memiliki kandungan eugenol yang terbukti sebagai karminativa, analgesik, dan immunomodulator [4], serta sereh (Cymbopogon nardus L. Rendle) yang telah terbukti sebagai antioksidandan sebagai imunomodulator [5].

Namun, belum ada penelitian yang menjelaskan kandungan dari salah satu zat berkhasiat utama yaitu eugenol. Eugenol merupakansalah satu senyawa dari kimia fenilpropanoid dan senyawa aromatis yang sangat banyak di alam. Eugenol bersifat mudah menguap dan bersifat sedikit asam

Informasi Artikel:

Submitted: bulan Januari 2022, Accepted: bulan Januari 2022, Published: Februari 2022

ISSN: 2715-3320 (media online), Website: http://jurnal.umus.ac.id/index.php/jophus 
serta larut dalam pelarut organik [6].Penelitian ini dilakukan dengan menggunakan terhadap zat berkhasiat utama eugenol setelah dilakukan pemanasan dengan menggunakan aquadestilata terhadap jamu empon-empon atau kombinasi dari tanaman-tanaman tersebut, sehingga perlu dilakukan analiais kualitatif maupun kuantitatif pada jamu empon-empon yang merupakan kombinasi dari tanaman rimpang jahe, rimpang temulawak, rimpang kunyit, kulit batang kayu manis dan sereh tersebut.

\subsection{Alat dan bahan}

\section{METODE PENELITIAN}

Alat yang digunakan yaitu alat gelas, seperangkat alat uji kromatografi lapis tipis, densitometer (CAMAG TLC Scanner 3), kompor listrik dan termometer suhu, timbangan elektrik (Mettler Toledo), Lempeng KLT silica, chamber. Bahan-bahan yang diperlukan dalam penelitian yaitu jamu empon-empon, aquadestilata, fase gerak,

\subsection{Jalannya Penelitian}

\subsubsection{Pengumpulan bahan}

Rimpang jahe, rimpang kunyit, rimpang temulawak, kulit batang kayu manis, dan sereh dikumpulkan sebanyak $1 \mathrm{~kg}$ yang didapatkan dari pasar Ajibarang Kecamatan Ajibarang Kabupaten Banyumas. Kemudian dibersihkan dari pengotor yang masih melekat pada tanaman dimaksudkan untuk mengurangi adanya kontaminasi mikroba atau kotoran lainnya. Pembersihan dilakukan dengan air bersih yang mengalir. Pembersihan ini memiliki manfaat untuk mengurangi kandungan peptisida yang tanpa sengaja menempel pada tamanan.

\subsubsection{Pembuatan jamu dan pembuatan ekstrak}

Penyarian senyawa pada tanaman basah rimpang jahe, rimpang temulawak, rimpang kunyit, kulit batang kayu manis dan sereh dilakukan dengan metode infusa (seduhan) yaitu dilakukan dengan mengekstraksi menggunakan air dengan suhu $90^{\circ} \mathrm{C}$ selama 15 menit [7]. Pada umumnya infusa dibuat dari tanaman yang memiliki jaringan lunak dan mengandung minyak atsiri serta zat-zat yang tidak tahan lama pada pemanasan[8]. Jumlah bahan yang dibutuhkan untuk membuat jamu untuk sekali minum yaitu $150 \mathrm{~g}$ jahe, $100 \mathrm{~g}$ temulawak, 150 g kunyit, 2 batang kayu manis, 2 batang sereh, dan $600 \mathrm{~mL}$ air [9]. Bersihkan dan potongpotong semua bahan-bahan, lalu rebus seluruh bahan sampai mendidih, dan saring air rebusan ke dalam gelas [10]. Setelah setiap bahan dilakukan perebusan dan jamu dibuat, maka dilakukan perubahan bentuk menjadi serbuk menggunakan alat freeze dryer.

\subsubsection{Analisis fitokimia ekstrak}

\section{a. Analisi kualitatif kandungan eugenol jamu empon-empon}

Jamu empon-empon, dan ekstrak air rimpang jahe, rimpang temulawak, dan rimpang kunyit, masing-masing diambil dan direbus dengan suhu $90{ }^{\circ} \mathrm{C}$ selama 15 menit menggunakan aquadest dalam flakon terpisah. Dalam uji KLT standard pembanding yang digunakan adalah kurkumin $10 \% \mathrm{~b} / \mathrm{v}$. Larutan yang telah disiapkan beserta standarnya, ditotolkan pada lempeng silica gel 60 F254 dengan fase gerak toluen: etil asetat: metanol rasio (65: 2,5: 32)v/v. Kurva baku dibuat dengan konsentrasi 10; 15;20; 25; dan 30 $\mu \mathrm{L} / \mathrm{mL}$. Sampel jamu dibuat dengan konsentrasi $20 \mathrm{mg} / \mathrm{mL}$ dan jumlah penotolannya 2 $\mu \mathrm{L}$, uji direplikasi sebanyak 3 kali. Profil kromatografi dari masing-masing ekstrak air akan dideteksi dengan sinar tampak, UV $254 \mathrm{~nm}$, dan UV 366nm. Pembacaan menggunakan TLC scanner atau densitometer pada panjang gelombang sample dideteksi pada panjang gelombang $254 \mathrm{~nm}$.

\section{b. Analisis kuantitatif kandungan eugenol jamu empon-empon}

Uji kuantitatif yang dilakukan pada penelitian ini dengan melihat berapa besar kadar kurkumin pada jamu empon-empon. Analisis kuantitatif dilakukan dengan mengukur hasil kromatogr menggunakan TLC scanner atau yang kita sebut densitometer. Plat KLT yang dibaca merupakan kromatogr. Dari pembacaan dengan alat densitometer akan didapat data berupa luas area dan profil KLT dari semua bercak yang 
terlusi pada proses KLT. Pembanding merupakan standar sebagai patokan untuk mengukur kadar dalam ekstrak air. Pengukuran kadar dilakukan dengan membuat kurva baku terlebih dahulu dengan konsentrasi $10 ; 15 ; 20 ; 25$; dan $30 \mu \mathrm{L} / \mathrm{mL}$. Setelah itu, volume penotolan dari sampel dimasukkan dalam persamaan kurva baku, maka akan

\subsection{Analisis Data} didapatkan nilai kadar kandungan pada masing-masing sampel.

Data yang diperoleh berupa hasil analisis kandungan eugenol dalam jamu empon-empon dengan menggunakan kromatografi. Data dianalisis secara deskriptif dengan menampilkan tabel dan gambar.

\section{HASIL DAN PEMBAHASAN}

Proses penarikan zat aktif dari rimpang jahe, rimpang kunyit, rimpang temulawak, kulit batang kayu manis, dan sereh dilakukan dengan metode infusa, dengan arti lain zat aktif yang terkandung dalam tanaman tersebut ditarik menggunakan pelarut aquadestilata. Penelitian ini memilih metode infusa dikarenakan mudah, murah, dan cepat, selain itu zat aktif yang diduga terkandung dalam tanaman tersebut dapat ditarik menggunakan pelarut air.

Pembuatan infusa ini dilakukan dengan cara menimbang masing-masing bahan setelah itu dilarutkan dengan menggunkan aquadestilata dalam panci infusapada suhu $90^{\circ} \mathrm{C}$ selama 15 menit. Ekstrak cair infusa digunakan untuk analisis kualitatif eugenol dalam jamu empon-empon. Setelah itu infusa diuapka terlebih dahulu untuk mengurangi kadar air sehingga akan lebih mudah untuk proses Selanjutnya. Penelitian ini menggunakan serbuk infusa untuk mengetahui rendemen infusa dari dari rimpang jahe, rimpang kunyit, rimpang temulawak, kulit batang kayu manis, dan sereh serta jamu empon-empon.Sehingga harus dilakukan perubahan bentuk menjadi serbuk dengan cara menggunakan alat freeze dryer. Pengeringan ini mempunyai keunggulan dalam mempertahankaan mutu zat aktif yang tidak tahan dengan pemanasan.

Rendemen ekstrak kental yang dihitung dalam persen bobot per bobot $(\% \mathrm{~b} / \mathrm{b})$ dengan membandingkan hasil serbuk infusa yang didapat dan jumlah tanaman basah yang digunakan sebelumnya (Tabel I). Perhitungan rendemen dilakukan selain untuk mengetahui persen bobot per bobot $(\% \mathrm{~b} / \mathrm{b})$ dari hasil serbuk infusa juga dapat digunakan untuk mengetahu senyawa bioaktif yang terkandung dalam bahan yang terekstraksi.

Tabel I. Hasil Randemen Infusa

\begin{tabular}{lccc}
\hline \multicolumn{1}{c}{ Sampel } & $\begin{array}{c}\text { Bobot } \\
\text { tanaman } \\
\text { basah }(\mathbf{g})\end{array}$ & $\begin{array}{c}\text { Serbuk } \\
\text { infusa }(\mathbf{g})\end{array}$ & $\begin{array}{c}\text { Randemen } \\
(\mathbf{\%} \mathbf{b} / \mathbf{b})\end{array}$ \\
\hline Jahe (A) & 54,6 & 1,26 & 2,307 \\
Temu Lawak (B) & 36,4 & 0,55 & 1,510 \\
Kunyit (C) & 54,6 & 1,36 & 2,490 \\
Kayu manis (D) & 9,1 & 0,05 & 0,549 \\
Sereh (E) & 27,3 & 0,8 & 2,930 \\
Empon-empon (F) & 182 & 3,25 & 1,785 \\
\hline
\end{tabular}

Berdasarkan data hasil penelitian dari berbagai sampel melalui proses infusa, rendemen ekstrak kental yang diperoleh berkisar antara 0,5495-2,490\%, sedangkan untuk ekstrak kental yang dihasilkan oleh infusa empon-empon adalah $1,785 \%$.

Jurnal Ilmiah Jophus Vol. 3, No.02, Februari 2022: 120-127 
Tabel I di atas menunjukkan bahwa hasil rendemen serbuk infusa tertinggi didapatkan pada ekstrak kental sereh dengan nilai 2,490\%, sedangkan rendemen serbuk infusa terendah didapatkan pada ekstrak kental kulit batang kayu manis dengan nilai $0,549 \%$. Besarnya nilai rendemen bergantung pada sifat kelarutan komponen bioaktif yang diekstraksi.

\subsection{Analisis kualitatif eugenol dalam jamu empon-empon}

Analisis kualitatif yaitu mengkonfirmasi adanya kandungan senyawa tertentu dalam ekstrak air (infusa) jamu empon-empon. Analisis kualitatif yang digunakan dalam penelitian ini adalah dengan menggunakan uji Kromatografi Lapis Tipis (KLT). Analisis dengan menggunakan KLT merupakan pemisahan komponen kimia berdasarkan prinsip adsorbsi dan partisi yang ditentukan oleh fase diam (adsorben) dan fase gerak (eluen). Komponen kimia tersebut naik mengikuti fase gerak karena daya serap adsorben tersebut tidak sama terhadap komponen-komponen kimia sehingga dapat bergerak dengan jarak yang berbeda berdasarkan dengan tingkat kepolaran dari masing-masing sampel.

Analisis KLT pada ekstrak dilakukan dengan menotolkan ekstrak pada plat KLT yang dielusikan dengan fase gerak [11]. Cara ini lebih dipilih dibandingkan dengan cara manual, terutama untuk sampel yang akan ditotolkan lebih dari $15 \mu \mathrm{L}$ dapat menyebabkan pelebaran bercak dan puncak ganda [12].Penelitian ini dilakukan untuk mengkonfirmasi adanya kandungan senyawa eugenol dalam ekstrak air (infusa) jamu empon-empon.

Eugenol merupakan senyawa yang memiliki rumus molekul $\mathrm{C}_{10} \mathrm{H}_{12} \mathrm{O}_{2}$ dengan nama IUPAC 4-alil-2-metoksifenol. Eugenol memiliki nama lain yaitu 4-alilguaikol, 1-allil-4-hidroksi-3metoksibenzena, asam kariofilik, 4-hidroksi-3-metoksialilbenzena, dan 2-metoksi-4-alilfenol. Eugenol memiliki sifat fisik yaitu berbentuk cairan tidak berwarna atau kuning pucat, bau kuat dan menusuk, serta menjadi gelap dapat mengental bila terpapar udara karena mudah teroksidasi [13]. Sifat lain dari eugenol yaitu memiliki titik didih $256^{\circ} \mathrm{C}$, titik leleh $-9^{\circ} \mathrm{C}$, titik nyala $104^{\circ} \mathrm{C}$, dengan tekanan uap $10 \mathrm{mmHg}$ pada suhu $123^{\circ} \mathrm{C}$, densitas $1,064-1,068 \mathrm{~g} / \mathrm{mL}$, berat molekul $164,20 \mathrm{~g} / \mathrm{mol}$ dan indeks bias 1,541 pada suhu $200^{\circ} \mathrm{C}$ [14].

Jamu empon-empon dalam uji KLT menggunakan fase gerak campuran toluen: etil asetat: metanol rasio (65: 2,5: 32) v/v. Fase gerak tersebut merupakan fase gerak yang dapat mengelusi eugenol. Jenis komposisi fase gerak ini mampu menghasilkan elusi eugenol dengan optimal.Sampel diambil pada konsentrasi $10 \% \mathrm{~b} / \mathrm{v}$ dengan volume spot $2 \mu \mathrm{L}$ dan diulang sebanyak 3 kali dengan volume yang sama. Perbandingan yang digunakan $10 ; 15 ; 20 ; 25 ; 30 \% \mathrm{~b} / \mathrm{v}$ pada volume titik pengukuran $2 \mu \mathrm{L}$. Analisis ini dilakukan dengan membandingkan antara eugenol murni dan ekstrak cair dari empon-empon.

Gambar 1 menunjukkan hasil kromatogr yang diperoleh dari uji KLT $10 \% \mathrm{~b} / \mathrm{v}$ emponempon. Ketika suatu senyawa diserap oleh eluen pada lempeng KLT, proses penyerapan berhenti jarak yang ditempuh ke atas lempeng aan semakin berkurang. Setelah terlihat adanya kenaikan bercak lempeng KLT dikeringkan lalu diamati di bawah sinar UV pada $366 \mathrm{~nm}$ UV dan $254 \mathrm{~nm}$ UV. Dari semua titik, ada kesamaan antara sampel dan pembanding. Artinya, hRf 74, menunjukkan fluoresensi coklat pada $366 \mathrm{~nm}$ UV dan menunjukkan fluorosensi kuning ketika diamati dari $254 \mathrm{~nm}$ UV. Fluorosensi merupakan terpancarnya sinar oleh suatu zat yang telah menyerap sinar atau radiasi elektromagnetik lain. Hal ini menunjukkan bahwa sampel yang digunakan mengandung senyawa pembanding yaitu eugenol. Banyaknya bercak yang ditunjukkan menunjukkan bahwa beberapa komponen senyawa dalam sampel bukan eugenol. Beberapa bercak memiliki bintik hitam pada hRf 74 jika dilihat pada UV 254. Oleh karena itu, pada sampel bercak muncul pada hRf 71, hal tersebut dianggap mendekati hRF eugenol yaitu 74, maka dinyatakan sampel mengandung eugenol. 


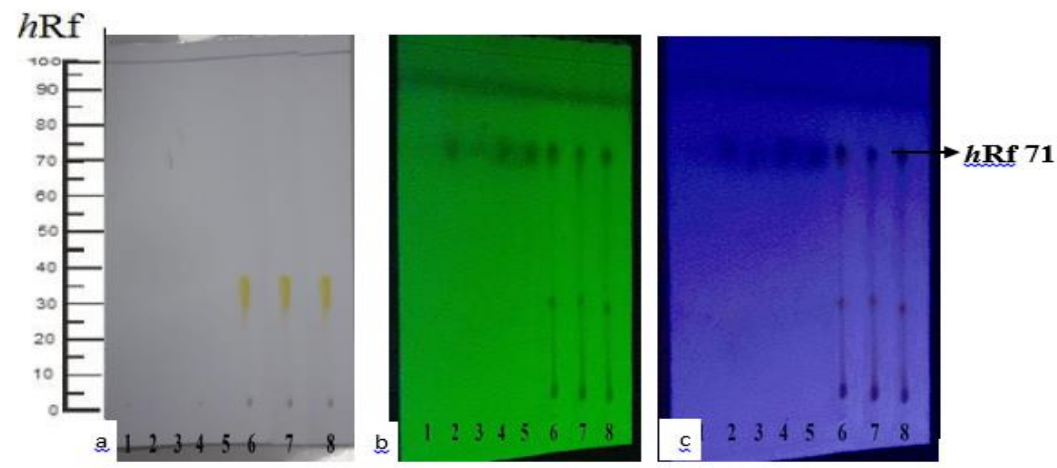

Gambar 1. Kromatogr Infusa Empon-empom Diamati Di bawah (a) Sinar tampak; (b) UV 254 nm; (c) UV 366 nm

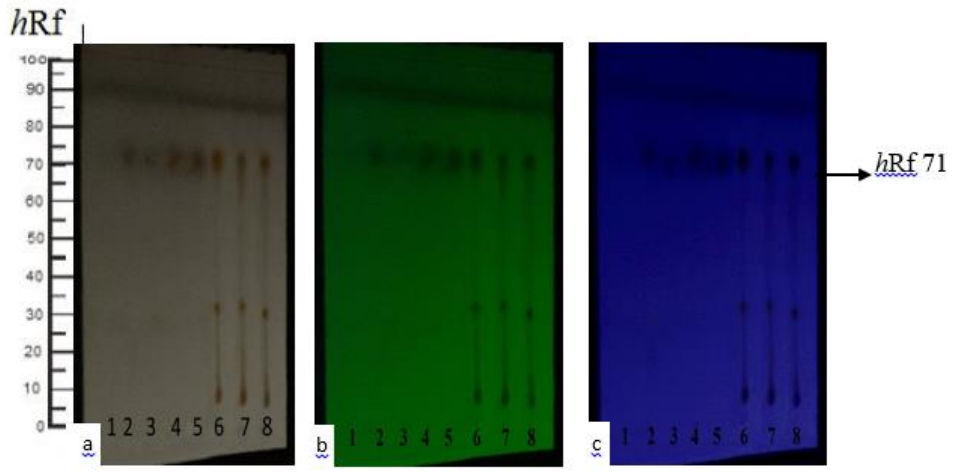

Gambar 2. Kromatogr Infusa Empon-empom yang Setelah Penyemprotan dengan Anisaldehida Asam Sulfat Diamati Di bawah (a) Sinar tampak; (b) UV 254 nm; (c) UV 366 nm

Deteksi bercak pemisahan pada KLT dapat dilakukan dengan mereaksikan bercak dengan suatu pereaksi melalui penyemprotan sehingga bercak menjadi jelas. Kromatogr infusa emponempon disemprotkan dengan menggunakan pereaksi semprot anisaldehid-asam sulfat. Alasan penggunaan pereaksi semprot ini karena anisaldehida-asam sulfat merupakan pereaksi yang bersifat destruktif karena pereaksi ini memecah senyawa pada plat KLT supaya mudah diamati oleh sinar tampak [15].

Setiap fraksi yang ditotolkan pada plat KLT disemprotkan dengan pereaksi anisaldehidaasam sulfat dan dipanaskan pada suhu $100^{\circ} \mathrm{C}$ selama 5-10 menit. Kemudian diamati dengan menggunakan sinar tampak UV $254 \mathrm{~nm}$ dan UV $366 \mathrm{~nm}$. Hasil kromatogr setelah disemprot ditunjukkan pada gambar 2. Jika senyawa tersebut merupakan eugenol atau golongan senyawa fenilpropanoid, deteksi AAS memberikan warna coklat kekuningan pada cahaya tampak. Spesimen dan klonnya memiliki warna yang sama dengan pembanding dan memiliki hRf 74 .

Beberapa titik lain juga memiliki warna kuning kecoklatan. Warna berubah dengan cepat dari kuning muda menjadi coklat tua dan dekomposisi termal senyawa menyebabkan warna merah menghilang, memutus gugus $\mathrm{OH}$ dan ikatan karbon. Ketika asam sulfat disemprotkan ke lapisan, ia bereaksi dengan gugus organik yang melekat pada lapisan fase diam. Jadi, ketika lapisan asam sulfat yang disemprotkan dipanaskan hingga $100{ }^{\circ} \mathrm{C}$ selama 5-10 menit, ikatan rangkap senyawa organik di lapisan itu putus dan terbakar dan karbon hitam dilepaskan, yang menggelapkan warna dan menjadi hitam di latar belakang [10]. Warna awal dari kuning muda ke coklat. Hal ini menunjukkan bahwa dalam pendeteksian senyawa $10 \% \mathrm{~b} / \mathrm{v}$ banyak terdapat senyawa fenilpropanoid yaitu eugenol.

Jurnal Ilmiah Jophus Vol. 3, No.02, Februari 2022 : 120-127 
Interpretasikan hasil sampel komponen $10 \% \mathrm{~b} / \mathrm{v}$ dan kromatogr eugenol $20 \% \mathrm{~b} / \mathrm{v}$ untuk perbandingan (Tabel II).

Tabel II. Hasil Kromatogr Empon-empon dengan Senyawa Pembanding Eugenol

\begin{tabular}{|c|c|c|c|c|c|c|c|}
\hline \multirow{3}{*}{ Totolan } & \multirow{3}{*}{$h \mathrm{Rf}$} & \multicolumn{6}{|c|}{ Warna } \\
\hline & & \multicolumn{3}{|c|}{ Sebelum disemprot } & \multicolumn{3}{|c|}{ Setelah disemprot } \\
\hline & & Tampak & UV 254 & UV 366 & Tampak & UV 254 & UV 366 \\
\hline $\begin{array}{l}\text { Standar } 1 \\
10 \%\end{array}$ & 74 & $\begin{array}{c}\text { Kuning } \\
\text { muda }\end{array}$ & $\begin{array}{c}\text { Kuning } \\
\text { kecoklatan }\end{array}$ & Coklat & Kuning tua & $\begin{array}{c}\text { Kuning } \\
\text { kecoklatan }\end{array}$ & Coklat \\
\hline $\begin{array}{l}\text { Standar } 2 \\
15 \%\end{array}$ & 74 & $\begin{array}{c}\text { Kuning } \\
\text { muda }\end{array}$ & $\begin{array}{l}\text { Kuning } \\
\text { kecoklatan }\end{array}$ & Coklat & Kuning tua & $\begin{array}{c}\text { Kuning } \\
\text { kecoklatan }\end{array}$ & Coklat \\
\hline $\begin{array}{l}\text { Standar } 3 \\
20 \%\end{array}$ & 75 & $\begin{array}{c}\text { Kuning } \\
\text { muda }\end{array}$ & $\begin{array}{l}\text { Kuning } \\
\text { kecoklatan }\end{array}$ & Coklat & Kuning tua & $\begin{array}{c}\text { Kuning } \\
\text { kecoklatan }\end{array}$ & Coklat \\
\hline $\begin{array}{l}\text { Standar } 4 \\
25 \%\end{array}$ & 74 & $\begin{array}{c}\text { Kuning } \\
\text { muda }\end{array}$ & $\begin{array}{l}\text { Kuning } \\
\text { kecoklatan }\end{array}$ & Coklat & Kuning tua & $\begin{array}{c}\text { Kuning } \\
\text { kecoklatan }\end{array}$ & Coklat \\
\hline $\begin{array}{l}\text { Standar } 5 \\
30 \%\end{array}$ & 74 & $\begin{array}{c}\text { Kuning } \\
\text { muda }\end{array}$ & $\begin{array}{l}\text { Kuning } \\
\text { kecoklatan }\end{array}$ & Coklat & Kuning tua & $\begin{array}{c}\text { Kuning } \\
\text { kecoklatan }\end{array}$ & Coklat \\
\hline $\begin{array}{l}\text { Empon- } \\
\text { empon } 10 \% \\
\text { replikasi } 1\end{array}$ & 71 & $\begin{array}{l}\text { Kuning } \\
\text { muda }\end{array}$ & $\begin{array}{l}\text { Kuning } \\
\text { kecoklatan }\end{array}$ & Coklat & Kuning tua & $\begin{array}{c}\text { Kuning } \\
\text { kecoklatan }\end{array}$ & Coklat \\
\hline $\begin{array}{l}\text { Empon- } \\
\text { empon } 10 \% \\
\text { replikasi } 2\end{array}$ & 71 & $\begin{array}{l}\text { Kuning } \\
\text { muda }\end{array}$ & $\begin{array}{l}\text { Kuning } \\
\text { kecoklatan }\end{array}$ & Coklat & Kuning tua & $\begin{array}{c}\text { Kuning } \\
\text { kecoklatan }\end{array}$ & Coklat \\
\hline $\begin{array}{l}\text { Empon- } \\
\text { empon } 10 \% \\
\text { replikasi } 3\end{array}$ & 71 & $\begin{array}{l}\text { Kuning } \\
\text { muda }\end{array}$ & $\begin{array}{l}\text { Kuning } \\
\text { kecoklatan }\end{array}$ & Coklat & Kuning tua & $\begin{array}{c}\text { Kuning } \\
\text { kecoklatan }\end{array}$ & Coklat \\
\hline
\end{tabular}

\subsection{Analisis Kuantitaif eugenol dalam jamu empon-empon}

Pada penelitian ini, analisis kuantitatif juga dilakukan untuk senyawa eugenol. Konsentrasi sampel yang digunakan yaitu $20 \% \mathrm{~b} / \mathrm{v}$ empon-empon, sedangkan konsentrasi kurva baku yang digunakan yaitu berturut-turut $10 ; 15 ; 20 ; 25 ; 30 \% \mathrm{~b} / \mathrm{v}$. Profil densitometry dua dimensi dan tiga dimensi data dilihat pada gambar 3 .
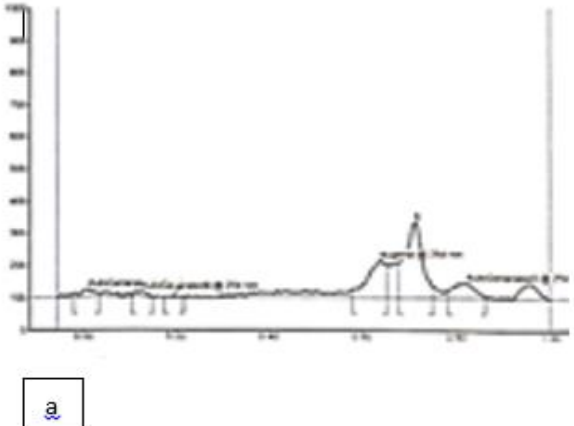

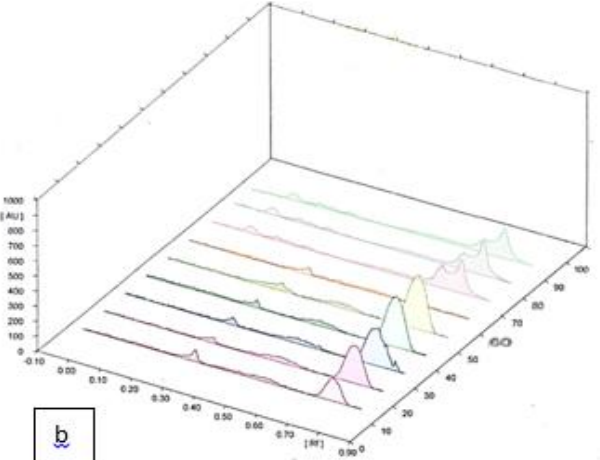

b

Gambar 3. Profil densitometri (a) dua dimensi jamu empon-empon (b) tiga dimensi empon-empon dan standar kurkumin

Berdasarkan kurva baku yang diperoleh, konsentrasi dan nilai luas area dimasukkan dalam perhitungan regresi liner sehingga diperoleh nilai $y=662,15 x+2270,7$ dan $R^{2}=0,9245$ sehingga diperoleh nilai $\mathrm{r}=0,962$. Berdasarkan persamaan regresi liner tersebut, dapat diperoleh rata-rata konsentrasi eugenol yaitu $49,28 \mu \mathrm{l} / \mathrm{mL}$, replikasi terperinci dapat dilihat pada tabel III. 
Tabel III. Data konsentrasi senyawa eugenol

\begin{tabular}{lrcc}
\hline Senyawa & Luas area & Konsentrasi & Mean \pm SD \\
\hline Eugenol Rep 1 & 34907,18 & 49,289 & \\
Eugenol Rep 2 & 34891,29 & 49,265 & $49,28 \pm 0,02$ \\
Eugenol Rep 3 & 34912,03 & 49,296 & \\
\hline
\end{tabular}

\section{KESIMPULAN}

Hasil rendemen serbuk infusa tertinggi didapatkan pada ekstrak sereh dengan nilai 2,490\%, sedangkan rendemen serbuk infusa terendah didapatkan pada ekstrak kulit batang kayu manis dengan nilai $0,549 \%$. Analisis kualitatif eugenol dengan menggunakan uji KLT menggunakan fase gerak campuran toluen: etil asetat: metanol rasio $(65: 2,5: 32) \mathrm{v} / \mathrm{v}$. setelah diamati di bawah sinar tampak tampak UV $366 \mathrm{~nm}$ dan Uv $254 \mathrm{~nm}$, sampel bercak muncul pada hRf 71 hal tersebut dianggap mendekati hRF eugenol yaitu 74, maka dinyatakan sampel mengandung eugenol. Pada deteksi senyawa yang menunjukkan adanya kandungan senyawa fenilpropanoid yaitu eugenoldilakukan dengan penyemprotan pereaksi anisaldehida-asam asam sulfat yang diamati dibawah sinar tampak UV $366 \mathrm{~nm}$ dan Uv $254 \mathrm{~nm}$ dengan hasil warna awal dari kuning muda ke coklat.Kadar senyawa marker yaitu gingerol pada jamu empon-empon (kombinasi ekstrak air jahe, temulawak, kunyit, kayu manis dan sereh) tersebut yaitu $49,28 \mu \mathrm{l} / \mathrm{mL}$ untuk eugenol.

\section{DAFTAR PUSTAKA}

[1] Semwal RB, Semwal DK, Combrinck S, Viljoen AM, "Gingerols and shogaols: Important nutraceutical principles from ginger", Phytochemistry, 117:554-568, 2015, [Online]

[2] Saraphanchotiwitthaya A, Ingkaninan K, \& Sripalakit P, "Immunomodulating activity of thai rejuvenating plants”, Naresuan University Journal, Vol.15(3):149-57, 2007, [Online]

[3] BPOM RI., "Pedoman Penggunaan Herbal Dan Suplemen Kesehatan dalam Menghadapi COVID-19 di Indonesia", 2020, E-book., ISBN 978-602-415-015-0

[4] Leijh, P.J.C., Furth, R.V. \& Zwet, T.L.V, "In Vitro Determination of Phagocytosia and Intercellular Killing by Polymorphonuclear and Mononuclear Phagocytes", In: Weir DM, Editor, Celluler Immunology, 2, Blackwell Scientific Publication, London, 74-85, 1986, [Online]

[5] Santoso, Hieraniyus, Budi, "Sereh Wangi Bertanam dan Penyulingan”, 1992, Yogyakarta. Kanisius

[6] Ketaren, "Minyak Atsiri”, 1987, Penerbit Universitas Indonesia Press. Jakarta

[7] Ansel, H.C, "Pengantar Bentuk Sediaan Farmasi", edisi 4, 1989, Jakarta : Penerbit UI press.

[8] Dirjen POM, "Farmakope Indonesia", edisi III, 1979, Jakarta : Departemen Kesehatan RI.

[9] Yasni, S. Imaizumi, K, Nakamura, M., Aimoto, J., dan Sugani, M, "Effects of Curcuma Xanthorrhiza Roxb. And curcuminoids on the level of serum and liver lipids, serum apolipoprotein A-I and lipogenic enzymes in rats", Fd. Chem. Toxicol., 31(3): 213-218, 1993, [Online]

[10] Gritter, R. J., Bobbit, J. M., \& Schwarting, A.E, "Pengantar Kromatografi”, Edisi Kedua. diterjemahkan oleh Padmawinata, K. 1991. Bandung: Penerbit ITB

Jurnal Ilmiah Jophus Vol. 3, No.02, Februari 2022 : 120 - 127 
[11] Stahl, E, "Thin-Layer Chromatography”, 2013, Springer : A Laboratory Handbook.

[12] Adamovics, J. A, "Chromatographic analysis of pharmaceuticals". (2nd ed), 1997, New York: Marcel Dekker.

[13] Budavari, S, "Merck Index : An Encyclopedia of Chemicals, Drugs, and Biological", 11 th ed, 1989, Merck \& Co., Imc., USA, 7.

[14] Widayat, Cahyono, B., Hadiyano, dan Ngadiwiyono, "Rancang Bangunan dan Uji Alat Proses Peningkatan Minyak Cengkeh pada Klaster Minyak Atsiri Kabupaten Batang”. Jurnal Ilmu Lingkungan, 2:161-166, 2012, [Online]

[15] Alegantina, S., A. Isnawati, dan I Rooslamiati, "Isolasi dan Identifikasi Artemisinin dari Herba Artemisia annua L", Buletin Penelitian Kesehatan. Vol. 38 (3) : 159-168, 2010, [Online] 